Cahiers d'études africaines

$240 \mid 2020$

Soudan : identités en tension

\title{
FADLALLA Amal H. - Branding Humanity: Competing Narratives of Rights, Violence and Global Citizenship
}

Siri Lamoureaux

\section{OpenEdition}

Journals

Electronic version

URL: https://journals.openedition.org/etudesafricaines/32888

DOI: 10.4000/etudesafricaines.32888

ISSN: $1777-5353$

\section{Publisher}

Éditions de l'EHESS

\section{Printed version}

Date of publication: 2 December 2020

Number of pages: 1026-1028

ISSN: 0008-0055

\section{Electronic reference}

Siri Lamoureaux, "FadLALla Amal H. - Branding Humanity: Competing Narratives of Rights, Violence and Global Citizenship", Cahiers d'études africaines [Online], 240 | 2020, Online since 02 December 2020, connection on 06 January 2023. URL: http://journals.openedition.org/etudesafricaines/32888 ; DOI: https://doi.org/10.4000/etudesafricaines.32888

This text was automatically generated on 6 January 2023.

All rights reserved 


\title{
FADLALLA Amal H. - Branding Humanity: Competing Narratives of Rights, Violence and Global Citizenship
}

\author{
Siri Lamoureaux
}

\section{REFERENCES}

FADLALLA Amal H. - Branding Humanity: Competing Narratives of Rights, Violence and Global Citizenship. Stanford, Stanford University Press ("Stanford Studies in Human Rights"), 2019, $198 \mathrm{p}$.

1 Those who have followed Sudan's conflicts over the years would be hard-pressed to read yet another analysis of Sudan's infamous "identity crisis." Refreshingly, Fadlalla does not come at the identity problem through its "roots"-be they political, historical, environmental, as has been the preoccupation of so much previous scholarship ${ }^{1}$ but at its performative encounters, the highly mediatized stories of ethnic and gender violence that have carved a groove in our minds through the humanitarian and human rights activism of the last three decades. Sudan's conflicts are not reducible to an Arab versus African ethnic and racial problem, but are linked with interests and events taking place at a global scale. Such dynamics work to inscribe the dichotomies of Arab/ African, Muslim/Judeo-Christian, North/South in Sudan as givens. While these polarizations may have been designed in the colonial and postcolonial era, they have been forcefully implemented as a nation-building strategy in the post-Cold War era, linked with Sudan's pan-Islamist vision in opposition to pan-humanitarianism, as a proxy for "the West." And, leading up to the secession of South Sudan in 2011-the time period of the author's fieldwork-they have been instrumental to transnational discourses by rights activists in opposing Sudan's Arab-Islamic government, in part justifying this separation, but also the neoliberal grip that humanitarianism sustains over its subjects. These constructs, she argues, may have little in common with realities 
and aspirations for the host of Sudanese living in Sudan or the diaspora, who must therefore rearticulate them to their own interests.

The book's five ethnographic chapters are organized into arenas of activism and can be read in any order. Chapter one traces the rise of "global citizens" through the positioning of "the Lost Boys," the famed child soldiers conscripted into the SPLA (Sudan People's Liberation Army) in the North-South civil war of the 1990s, orphaned and resettled in the United States in the 2000s. Through engagements with faith-based (mainly Christian or Jewish) NGOs in the United States, the Lost Boys are made to be hardworking citizen-refugees. These reformed subjects are now celebrity humanitarian performers of the rescue/salvation narrative, upholding Western neoliberal values and undermining the oppression of Sudan's Islamist regime.

The second chapter documents the emergence of "humanitarian publics" in the US during the Darfur conflict of the early 2000s. Situating the mediatization of this violence in post-9/11 America, and the "War on Terror," it participates in the same moral East/West rivalry as above. However, in Darfur, where Christianity is absent, it is reconstrued as bad-Arab-Muslim versus good-African-Muslim. Her case studies include rallies and protests in Washington D.C. held by Save Darfur, the initiatives of humanitarian celebrities George Clooney and John Prendergast, and the rights work of STAND (Students Taking Action Now: Darfur). She details how such activism shapes public opinion, simplifies political realities in Sudan, and rebrands them as moral issues. Drawing on the irony of this form of humanitarianism, however, the book's headline "Branding Humanity" indexes how such forms of intervention are justified by the commodified, ready-to-consume narratives of violence by charitable media audiences, and sympathetic humanitarians abroad, and transformed into socioeconomic and political capital for activists to further their causes of building a future for South Sudan. Chapter 3 argues that such polarized "competing" identity narratives elide the variations and differentiations of visions and aspirations of other Sudanese "secular activists" who are invested in constructing a life as Sudanese Americans. This argument emerges more clearly in her narratives of several northern Sudanese community activists in the Washington D.C. area who are participating in local organizations that support, for example, women's rights, or fundraising activities, involving Sudanese musicians, business leaders and other benevolent actors. The Sudanese diaspora reconstruct their "Sudanese-ness" through experiences of mutual "suffering" abroad.

Chapter 4 zeroes in on the instrumentation of "affective violence" by which the author refers specifically to accounts of ethnic and gender-based violence-those that evoke compassion for feminized and infantilized victims. Her cases range across contextsfrom depictions of rape in Darfur, to the massacre of Sudanese refugees in Mustafa Mahmoud Square in Cairo, to the refugees attempting to cross Sinai and seek refuge in Israel, in politicized processes of side-taking. Juxtaposed to these stories are forms of humanitarianism taking place among Sudanese civil society that take issue with socioeconomic disparities rooted in narratives of cultural erosion. Lastly, chapter 5 tells the story of one highly mediatized episode when a group of women were arrested for wearing pants in a Khartoum restaurant. One of the women was an influential journalist, Lubna, whose trial became an event for feminist criticisms of Sudan's stringent dress code based in its interpretation of shari'a law. And yet, the hypervisibility of this case, and its co-optation by powerful actors including France, 
who offered political asylum to Lubna, worked to obscure the agency of women's voices.

5 Fadlalla situates her inquiry in the literature on globalization, transnational humanitarianism and human rights of the late 1990s and early 2000s, particularly in the work of Arjun Appadurai, Lisa Malkki and Aihwa Ong on flexible citizenship, refugees, identities, and global flows, and in the work of Didier Fassin on the politics of humanitarianism and compassion. Her work is multisited, meaning, she collected circulating narratives from a variety of events including rallies and protests, seminars and conferences, a beauty pageant, festivals and other in person as well as online fora, namely the ever-popular SudaneseOnline. She works with these observations as well as interviews and press media (p. 24). In her selection of predominantly performative moments, the bulk of her data reinforces the dichotomized constructs of the good guys versus the bad guys, whoever they are at that moment in that setting, and how they are mobilized.

6 That said, the reader could have benefited from more attention placed on the everyday business of being a Sudanese-American migrant. One could surmise that only one crosssection of the diaspora is engaged in Sudanese identity politics while a great many others are going on with their lives. Although hinted at in various chapters, the reader wonders if the author will take us deeper into these experiences and aspirations. Some terms are somewhat loosely applied. For example, there is a frequent reference to "the politics of" this or that, without much elaboration. Similarly, the word "transnational" is perhaps overly-used, appearing sometimes twice in a sentence. By "transnational," the author refers to American Christian and Muslim alliances, "the West" generally, politicians and journalists, Hollywood celebrities, NGOs, states, but also, various Sudanese social activists in the diaspora. One wonders if this term captures the important differences between these actors. In terms of organization, it isn't until a discussion on pages 177-178, that what seems to be the most important argument emerges in more detail, concerning the call to situate simplified narratives of affective violence in their socioeconomic, political and historical contexts. If this empirical argument, coupled with a conceptualization of the power and circulation of master narratives, came at the beginning, the reader could more easily follow the arc of the rich ethnography.

7 Overall, this book is an important contribution to the literature aiming to deconstruct Sudan's identity crisis, and reveal the host of actors and interests that are involved in reinforcing or rearticulating such polarized notions. Joining the likes of Alex de Waal and Mahmood Mamdani, Fadlalla's ethnography should be read by any scholar interested in how global dichotomizing discourses of "West" and "East" are instrumentalized and propagated.

\section{NOTES}

1. See e.g. D. H. Johnson, The Root Causes of Sudan's Civil Wars, Oxford, James Currey, 1997. 


\section{AUTHOR}

SIRI LAMOUREAUX

University of Siegen, Germany 